This is the accepted version of the article:

BONET, M., GUIMERÀ, J.A., 2016. When efficiency meets clientelism: spectrum management policy and broadcasting model. The Spanish case. European journal of communication, vol. 31, no. 4, pp.411-425.

DOI $10.1177 / 0267323116655511$

This version is available at https://ddd.uab.cat/record/183728 under the terms of the $\mathrm{OR}$ Rights Reserved license

\title{
When efficiency meets clientelism: spectrum management policy and broadcasting model. The Spanish case ${ }^{1}$
}

Montse Bonet and Josep Àngel Guimerà i Orts

\begin{abstract}
According to the predominating discourse, the radio spectrum has been converted into a technological platform of strategic importance for the economic development of countries. Wireless Internet and the promises of access at 'any time, in any place' add political and economic pressure to a platform, which has been an almost exclusive monopoly of radio and television for years. The main aim of this article is to study the radio spectrum management in Spanish broadcasting from its origins until the present day. The article also seeks to show the existing relationship between how frequencies are managed and the resulting broadcast model.
\end{abstract}

\footnotetext{
1 This article is part of an international research the first author is working on. Further information: http://montsebonet.net/transitions-broadcasting-policy-technology/; $\quad$ http://www.uta.fi/cmt/postbroadcast/focus_a.html.
} 
Keywords radio spectrum, radio, television, Spain, clientelism

Radio was not born as a medium for mass communication but rather as a means of point-to-point communication, to serve commercial and military interests. What was originally called 'wireless' became, around the 1930s, 'radio', and what had been point-to-point telecommunication became broadcasting, i.e. point-to-masses transmission (Lewis and Booth, 1990). In this regard, it should be noted that although there were researchers, amateur enthusiasts, armed forces, shipping companies, large electrical equipment manufacturers and many others behind the birth of radio (and later television), different governments soon decided to intervene in order to gain control over it. There were three basic motivations for doing so: First, to avoid interference between broadcasters, and, second, the need to prevent broadcasting from being able to influence the population in certain ways. Two wars, the Spanish Civil War and the Second World War, are good examples of what could be achieved using the nascent mass media (Hale, 1975). Finally, the limitations of the platform itself led governments to treat the radio spectrum as a public asset that required control and organisation. In fact, the differences between the main broadcasting models around the world (public, private and mixed) were (and still are) focused on who can and cannot make use of radio spectrum and how. And that owner was the State, in all countries, including the United States.

Hence was born the myth of a lack of frequencies, which time has proven to be mistaken. The spectrum is not sparse, but it is limited and requires rational and efficient management. The difference is one of nuance, but it is an important one. Of the total of the electromagnetic spectrum, the range of especially appropriate frequencies (coverage, extension, quality) for radio-diffusion was limited. The new 
consumption ways of audiovisual products of all types, together with the advantages of an Internet without wires, has added pressure among stakeholders struggling for the same range of frequencies (UHF band); wireless Internet is ideal not only in specific geographic zones of difficult access or where the deploying of the cable is too expensive, but rather it is also the way to keep the promise of rapid and immediate access in any place and at any time.

For this, studies on TV White Space (TVWS) abound (Ko et al., 2014), the auctioning of digital radio frequencies such as downlink for mobile-phone companies (European Commission, 2015a) has begun, and the social character of the spectrum is claimed, even defending it from the activism standpoint (Dunbar-Hester, 2009). Nobody wants to be expelled from the UHF band.

\section{Object of study and objectives}

The object of this article is the management of radio spectrum for its use in broadcasting in Spain from the early $20^{\text {th }}$ century until the early $21^{\text {st }}$ century. In turn, the main objective is to analyse the existing relationship between the conception and management of airwaves and the resulting broadcasting model in this country. This is an important historic moment in which a new digital audiovisual system is being created and, in it, the radio spectrum has a decisive role reserved for it. To understand how the spectrum has been managed until now helps in seeing, with more clarity, how this new system can be outlined.

Several previous studies by authors on the subject of both radio (Bonet, 2007, 2012; Arboledas and Bonet, 2013 and 2014; Bonet and Arboledas, 2011; Bonet et al., 2009) and television (Guimerà and Bonet, 2012; Guimerà and Blasco, 2012; Guimerà, 2006 and 2014; Bonet et al., 2014) and the liberalization of radio spectrum, digital 
dividend or the switch-off (Bonet et al., 2008) offer suggestions of unprofessional and highly politically motivated management both in terms of radio and television. Studies by other authors (García Leiva and Starks, 2009; García Leiva 2009 and 2013; Cullell, 2011; Schumann, 2011; Fernández-Quijada and Arboledas, 2013; Massaro, 2013; Harvey, 2014; Ala-Fossi and Bonet, 2015; Delgado, 2015) indicate the same kind of tendency regarding the future of broadcasting and the key role radio spectrum is playing.

Based on this set of indicators and evidence, the general hypothesis underlying this research is that, in Spain, a policy of 'occupation' of the spectrum guided by political and clientelistic interests has always prevailed, which has impeded any professional attempt to define a rational and efficient broadcasting model, both under the Dictatorship and in times of Democracy. In other words, the political system and its needs have defined the model for the use and management of the spectrum, which has been regulated on the basis of a fait accompli or following a judicial overturn.

This article pursues two specific objectives: First, to systematize the existing knowledge of the management of radio spectrum in Spain in relation to different media and at different moments in history, and, second, and derived from the former, to validate this image of occupation of the spectrum as outlined by previous partial studies. This will obtain an overview for Spain at a time when radio spectrum has become a central issue around the world. It should be made clear that the aim is not to produce a detailed description of the historical process in question but rather to focus on four key moments: the birth of broadcasting; the irruption of the Franco dictatorship and its subsequent consolidation; the transition to democracy, and the digitalization process. In accordance with the above, the methodological design is 
based on documentary analysis, applied both to previous research and to European and Spanish legislation. The authors have not limited their work to revisiting previous studies, but have also gone back to analyse the regulations from a new perspective. The basic purpose of the review is to identify the most relevant actions and decisions affecting the organization of the spectrum. That is to say, that a transversal and historic documental revision has been made which puts the spotlight only on the management of the spectrum, until now not dealt with this depth, since the studies on clientelist systems usually centre on the contents, the level of politicisation, organisation, etc.

\section{Theory framework}

The research carried out to elaborate this article has needed a theoretical framework that permits it to take on, on one hand, the notion of efficient management of the spectrum and, on the other hand, the logics of political intervention upon the system of media in the Western democracies. Without a clear definition of the first one, it becomes very difficult to identify and tackle the politicisation of the spectrum, which is proposed in our hypothesis.

In this sense, before taking on the theoretical perspective of our study, it is necessary to define, due to its importance, the idea of efficiency, with respect to the management of the radio spectrum. Purely technical criteria exist in order to define what is the efficient use of spectrum (ITU, 2006), but in terms of management (closely linked to economic criteria), it refers to avoiding an under-utilisation of the frequencies (RSPG, 2014).

In relation to the use of the spectrum, Directive 2002/21/EC indicated the idea, recurring in this type of documents, that it is important to 'manage the attribution and 
the assignation of frequencies of the most efficient manner possible' (pg. 35). The same can be read in other documents such as Decision 676/2002/EC (also known as DER) or the Review of the regulatory framework of the UE of the networks and services of electronic communications of 2006 , by affirming the need of introducing new forms of spectrum management and licencing 'so as to promote economic and technical efficiency in the use of this valuable resource' (pg. 7). These are only some examples of what is repeated endlessly in hundreds of documents, reports, studies and

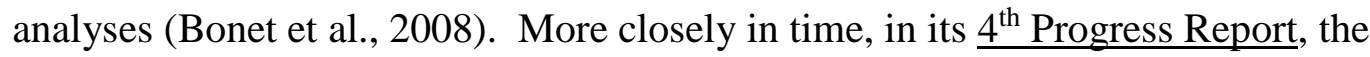
Radio Spectrum Policy Group (European Commission, 2015b) dedicates one of its chapters to include, among other themes, questions concerning licence duration and renewal, spectrum fees, refarming, competition, coverage obligations, standardisation, and management of under-utilized spectrum. Frequently it is forgotten that, whatever the degree of benefits that is obtained from the spectrum, 'it should have repercussions, in the final instance, in the whole of society' (GRETEL, 2007: 19). This same research group (2007: 31) proposes three dimensions of efficiency: technical, social and economic, and it reminds us that one should never forget that the ownership, management, planning, administration and control of the spectrum correspond to the State and should guarantee that the citizenry be the principal beneficiaries. For this, 'the efficient use is presented as the guarantor, the backbone that should marry the safeguarding of the public good to its new role of the generator of wealth and prosperity' (Bonet et al., 2008: 54).

For all of this, in this article, the word 'occupation' is used in the metaphorical sense of 'being inside'; even though the frequency awarded is not being used, this does not imply for the radio or TV station being expelled from the spectrum. In summary, 
when the minimum requisites for the guarantee of efficiency are not fulfilled because the clientelist political factors are favoured.

Once these concepts are clarified, we have reviewed and analyzed the history of broadcasting as well as the past spectrum policies in Spain combining two different theoretical artefacts, the transition models by Jakubowicz $(2004,2008)$ and Jakubowicz and Sükösd (2008); and the categorization of media systems in democratic societies developed by Hallin and Mancini (2004), in which Spain represents the polarized pluralist model.

On the one hand, the idealistic / mimetic / atavistic model (Jakubowicz, 2004, 2008) explains transitions in the media from authoritarian political systems to other democratic ones (specially, post-communist societies). Briefly said, the mimetic model seeks to transfer the Western media model, with freedom of press and a dual radiotelevision system, while the atavistic represents the maintenance of control over the media, like in the past, even though the country has democratized. The authors (2008) consider the atavistic model to be predominant in less democratic countries. Although it formally could be among the countries that followed a mimetic orientation, in practice the atavistic orientation was imposed in Spain, because the reforms were insufficient (Arboledas and Bonet, 2014). In fact, it has a certain degree of logic because, as Jakubowicz and Sükösd (2008: 19) very well point out, upon referring to the public service broadcasting in Mediterranean Europe, this service 'is as distant from the ideal of independent public service media, as it is in post-communist countries', because in some cases an excessively idealized and difficult-to-achieve model in its first stage of transition has been sold. According to these authors, this defines the atavistic model as a partitocratic system that substitutes civil society in 
great measure and in which the political parties accept the transition before the public but they continue holding on to some defining elements of the ancien_regime.

On the other hand, according to the categorization of media systems in democratic societies developed by Hallin and Mancini (2004), Spain could be said to have a pluralist, polarized or Mediterranean media system, founded on major State intervention. Of all the characteristics defining it, those covered here are the major political parallelism of the media with respect to political ideologies and the parties that represent them; the political instrumentalisation of the media by both political and economic agents; the absence of a rational-legal authority to guarantee formal and generalized standards of governance; and the major clientelism that typifies relations between the State and the private sector. These four elements are essential for understanding the management of radio spectrum and, therefore, how the present-day Spanish audiovisual system was configured.

(Table 1. Atavistic and Polarized models vs. Efficiency)

Hallin and Mancini (2004) include clientelism among the defining elements of the Mediterranean model. Previously, Hallin and Papathanassopoulos (2002) had already indicated the instrumentalisation of private media or the politicisation of public broadcasting and media regulation as two of the elements that define the relation of the media system with clientelism policy. Jakubowicz and Süskösd (2008) consider it to be a distinctive and dominating element of some mediatic systems, in which political power offers something (in our case, radio and television frequencies) in exchange of editorial support from the medium. 
The Spanish case has one more peculiarity: The press made a pact with the political forces in the first years of the Transition (those most fragile and full of attempts and a failed coup d'état) to strengthen the brand-new democracy, but this 'agreement' lasted too long, preventing the press from evolving towards a more mature and less partisan media system (Papatheodorou et al., 2003).

\section{Spain within the European context}

Throughout the deregulation process that began in Europe in the 1980s, both regarding telecommunications and the audiovisual industry, the radio spectrum played a central role, as 'scarce' common asset (or 'limited', depending on variations in institutional discourse over time) that due to digitalization lost its status as a single channel (i.e. when a frequency was equated with a programme) and fitted into the same platform category as satellite or cable broadcasting. Electronic communications (i.e. audiovisual services via mobile) gained a new importance, thus putting a check on the traditional broadcasting service. Radio and television were no longer the one and only user in some spectrum bands. In short, this is an economic battle between two ways of understanding mass communication and its business model, and the radio spectrum is the battlefield (Ala-Fossi and Bonet, 2015; Bonet et al., 2008; European Commission, 2005 and 2007; GRETEL, 2004; Hellman, 2010; Mullooly, 2012).

From the first Green Paper on convergence (1997), through the Green Paper on radio spectrum policy (1998) and its results (Next steps in radio spectrum policy, 1999) and until Pascal Lamy's Report (Results of the Work of the High Level Group on the Future Use of the UHF Band 470-790 MHz) in 2014, Spain has been transposing the different European standards. It implemented its analogue television switch-off in 2010 and left its digital radio (DAB, Digital Audio Broadcasting) on stand-by (frequencies were awarded but are barely in use). The Spanish government 
had difficulty in complying with the periods established for the digital dividend, which affected the $800 \mathrm{MHz}$ band, while like other countries around the world, it was preparing for the World Radio-communication Conference, WRC-2015.

Of the different types of spectrum management ('command and control', 'market-based', 'licence exempt') Spain has adopted the classic 'command and control' model, the basis of which is State control over the planning and use of the spectrum, whereby it is decided who is granted which part of the spectrum and for what purpose (García Leiva, 2013; Hendriks et al., 2011). This is the model that started to face serious criticism from the 1990s due to its lack of flexibility following the appearance of new wireless services (Analysys Consulting et al., 2004; EBU, 2012; European Commission 2005, 2007). In the $21^{\text {st }}$ century, the economic strength promised by new broadband services is threatening this form of management further still.

Within this model, there are different ways of awarding frequencies. In the Spanish case, the respective Ministry (which in 2016 is the Ministry of Industry, Energy and Tourism) is in charge of radio spectrum planning and distributes radio and television frequencies to each of Spain's 17 autonomous communities. It is the Government of Spain, not the national regulatory body (National Commission of Market and Competence, CNMC, created in October 2013), that grants national radio and television licences, and all but one of Spain's regional governments grant regional and local licences. The exception is Catalonia, where the regulatory authority (Catalan Audiovisual Council, CAC) awards licences. The tender system is used, also known as the 'beauty contest' (Hendricks et al., 2011). This process and the different concessions made in Spain since the return to Democracy have been permanently contested, criticized and doubted in terms of their objectiveness and meritocratic 
nature (Fernández-Quijada and Arboledas, 2013; Arboledas and Bonet, 2014).

To better understand what the article aims to show, we should note that Spain is a country in which such platforms as cable and satellite are still residual in comparison with the terrestrial radio and television platforms. According to the latest data of AIMC (2015), terrestrial television has a penetration of $88.4 \%$. This obviously means that airwave management plays a central role in the configuration of the media system.

\section{Back to the origins}

Spanish radio, as we understand it today, was officially born, after years of testing, in 1924, at the height of the Primo de Rivera Dictatorship. At first, there was only private radio, which could broadcast thanks to a concession granted by the State. In 1932, the first signs of occupation of the spectrum emerged when local radio was created in Spain. Its appearance was not the result of planning or a premeditated project, but instead it was an attempt to reach every corner of the country, so private initiative achieved what the State did not. Because since 1929 the government had been trying to create a public radio network without success, given the turbulent political situation at the time. This solution was something of a half measure, as the maximum authorized transmission potency for local radio was 200 watts and there could be no more than one station per town or city. Up until 1932 there were only eight radio stations, but from that year on and until the outbreak of the Civil War, the figure would rise to almost seventy. In short, neither a strong State broadcasting system was created (not until 1937) nor were private initiatives allowed to make one under equal conditions. 
Once the conflict was over, the peculiar mixed Spanish model was created, for Franco did not do away with private initiative, although he did subject it to a severe process of ideological filtering. Under Franco, there were two major stages in terms of the management of the spectrum and the configuration of the radio model.

a) The period just after winning the war was characterized by Spain's lack of participation in international agreements, as a result of Franco's economic autarky, and the isolation imposed by some international bodies. This implied its absence from different conferences at which frequencies were distributed. From the 1940s to the 1960 s, authorisations were granted to create new radio stations to cover as much of the territory as possible, while extension of the national public network was completed. This could be considered the period of uncontrolled occupation of the spectrum by the state itself, when radio frequencies were used to pay the loyal groups that helped him to win the war.

b) But in the late 1950s, an attempt was made to rectify this situation in which quantity meant more than quality, when Spain started to be reaccepted back onto international forums. At that time, the uncontrolled growth of radio frequencies in Spain caused interferences and was heavily criticized around Europe, hence the need to restructure the broadcasting panorama. A 1958 decree, the basis for the Transitory Plan of 1964, could be described as the moment when Frequency Modulation was officially born in Spain. The Plan meant the disappearance of many local broadcasters and the obligation for AM stations to broadcast simultaneously in FM. As a result of this, Spain joined the 1948 Copenhagen Frequency Plan. The limitations of medium wave bands and the impossibility of more broadcasters proliferating were the arguments 
that justified the change. Spain went from having 400 to 167 AM radio stations. But, as we shall see later, this situation did not last for long.

As for television, its appearance in 1956 consolidated the typical broadcasting model of a dictatorship, for like radio it was used as a propaganda weapon. Television first appeared in times of financial hardship (autarchy was crippling Spain) and of political turbulence (due to the disputes between factions of the regime); and it lacked order, agreements or models. It had no labour or legal structure as a company. The lack of direction and the reluctance to apply any licence fee meant that Spanish television, from the outset, was reliant on advertising; despite being a public television, it was also commercial.

This was therefore a considerably complex model that would affect the future development of both media:

a) It was a broadcasting model based, like in the other Western European countries, on the laws of the radio-communication sector and not the experiences of the printed press, as in the USA.

b) Under Franco, radio was a mixed system, while television was a public monopoly.

In summary, with this entire context, in Spain the radio spectrum was clearly important to: a) monopolize television; b) distribute radio frequencies as 'gifts' without caring about the efficient management of the platform.

\section{Transition and democracy}


Spain entered the democracy game just as the rest of Western Europe was starting to develop the deregulation process.

In radio, democracy brought with it a series of technical plans. That of 1978, the last to be made in Spain for AM frequencies, allowed no increase in the private sector, but easily doubled the number of public stations. Another example of the occupation and accumulation of frequencies in those years, following a more political logic than one of efficient management, was the successive allocations of FM frequencies, more or less every ten years, even though it was always said that there was no room for more. As for the private radio sector, the successive extensions of the FM spectrum in 1979 (300 frequencies), 1989 (352), 1997 (350) and the last one in 2006 (866) were, in all cases, a mess of denunciations and accusations of favouritism (Arboledas, 2009; Arboledas and Bonet, 2014). It is beyond the scope of this article to provide a full review of archives and bibliography, but the fact is that, as more than one study has shown, the structural bases, despite the differences, are still the same as they were in the Franco era (e.g. Arboledas and Bonet, 2014), with the awarding of frequencies to large media groups that are supportive of the political party in power (i.e. PRISA, Godó, Mediaset, Atresmedia). Clientelism and the political instrumentalisation of the radio spectrum plays a major role in these tenders, as each government (whether national or regional) tends to grant licences to the companies that it considers to be supportive (Arboledas, 2009; Arboledas and

\section{Bonet, 2014; Fernández-Quijada and Arboledas, 2013).}

One of the most controversial and obvious examples of the occupation of the spectrum and a posteriori regulation was the so-called 'Pilot Plan'. In late 2002, it was known that the autonomous Catalan government had made a pact with the association of private Catalan radio stations (Associació Catalana de Ràdio) in order for some of 
them (i.e. SER, COPE, R. Estel, RAC 1, Onda Rambla, among others) to be able to occupy twenty frequencies (the number would later be increased), which enabled them to extend their coverage. At the same time, this was considered a way by which the Catalan government and radio private sector put pressure on the Spanish government to plan a new distribution of licences throughout Spain, to show that there was still a free radio spectrum available. Theoretically, the plan was to last for only six months, after which a tender would be called, and did not represent any definitive right for the beneficiaries. The Plan did not last six months but rather almost six years and was possible thanks to a political agreement between central and regional governments that was outside of the legal framework of the time. Finally, in 2008, these frequencies were awarded, and in almost all cases to the same radio groups that were already making use of them (e.g. Spanish radio groups Cadena SER,

Cadena COPE, Vocento or former Grupo Antena 3, now Atresmedia; or Catalan radio groups like Godó, Grup Flaix or Ràdio Estel).

The management of television frequencies in the eighties and nineties followed a very similar pattern to that of radio. With the arrival of democracy, a dual transformation process occurred in the sector: decentralisation and liberalisation. In ther early 80s, local public and private televisions and regional public channels started broadcasting. At the end of the decade, national private television stations were born. As we argue in the following lines, decentralisation was a clear example of the primacy of political interests over technical or legal ones; that is, more political

\section{than rational.}

The birth both of regional and local television was not an orderly process that was fostered or managed by central administration. At first, the pioneering regional televisions (ETB in the Basque Country and TV3 in Catalonia) arose out of pressure 
from the respective regional governments, who wanted their own television channels despite the reticence of the central executive. Both Basque (1982) and Catalan (1983) television started broadcasting despite not having central government's permission to use the frequencies and without there being any law in force to allow this. A similar conflict arose when the Basque (1986) and Catalan (1989) governments decided to create a second regional channel, ETB2 and Canal 33 (despite this not being permitted by the law). The first Basque and Catalan channels were regulated $\underline{\mathrm{a}}$ posteriori but the second ones were just politically tolerated even though they were manifestly illegal (Fernández and Santana, 2000; Authors, 2012).

In turn, local television emerged by initiative of city councils and local entrepreneurs, who set up channels despite the law not providing for such things. None of these channels -897 in the early 2000s according to AIMC (2002)- were fully regulated until 2005, after a previous attempt to legalize them in 1995 had failed. In other words, for more than 20 years, local television channels were broadcasting (some promoted by the local administrations themselves) without State permission and without the latter going to any major effort to prevent them from existing or to control their proliferation any further than the first few years (Guimerà, 2006). At this point, it should be recognized that, compared with decentralisation, liberalisation was controlled: in 1989 the three private national television channels allowed by the law were launched (Telecinco, Antena 3 and Canal Plus). However, in this case, central government was also accused of favouritism in granting licences to entrepreneurs that were ideologically or personally close to the party in power. (Fernández and Santana, 2000).

\section{Digital occupation of the spectrum}


DAB in Spain does not work, and all stakeholders are in agreement with the fact that its implementation as a technological audio standard was a failure (Bonet et al., 2009) and it illustrates how, in spite of not using the frequencies, the licensees don't lose their rights over the licenced spectrum. Broadcasters have managed to reduce the obligations included in the licence by not paying the fee for the use of radio spectrum or extending the periods to cover the whole territory. But the frequencies are still being occupied, to the extent that a tender was called in 2011 to award licences in the Balearic Islands, thus repeating the pattern of giving licences to companies that do not use them. At the time of writing, none of the winning companies are broadcasting, but they are already occupying the frequencies

Meanwhile, the management of the implantation of DTT (Digital Terrestrial Television), which should have involved a complete overhaul of the television system, did not elude the logic of politics and occupation either. The process began in 1998 with a model based on the nationwide pay-TV platform, like in the UK (Iosifidis, 2011), that would exploit three and a half MUX (multiplexer) of the five foreseen (with the capacity for four channels each). The other half MUX was to be exploited by two new private operators (one channel each) and the remainder would be shared by three private analogue televisions and the two analogue channels of national public broadcaster RTVE. Once again, the tender for concessions was accused of clientelism of the ruling party, PP (Partido Popular, People's Party). The winner of the three and a half MUX was Onda Digital, controlled by Retevisión, formerly a public company privatized shortly before by the government, and at the time headed by a person who would become a minister months later. The new private operators were Vocento and Unedisa, center-right publishers very active against the previous socialist government (Fernández-Quijada and Arboledas, 2013). Moreover, 
the model was clearly opposed to the market reality and in 2002 Onda Digital went bankrupt and left the MUX that it had occupied free.

It would not be until 2005 that a new government, this time of PSOE (Partido Socialista Obrero Español, Spanish Socialist Workers' Party), would restructure the spectrum: it distributed the available multiplexers to the surviving private operators and the public RTVE. But in defiance of all logic, in 2006 the same government called a tender for the creation of a new private state television, which was also to broadcast analogically. The winner was, once again, an entrepreneur close to the ruling government (La Sexta, formerly owned by Mediapro, and now part of Atresmedia). In 2010, and after the analogue switch-off, the national DTT map was completed. The executive awarded, without any tender, a greater number of MUX to the operators in order for them to extend their offer. This decision, which went against the law, ended up in court and ended in 2014 with a sentence that ordered the Government to shut down the nine channels that had been granted illegal licences in 2010. As a result, Atresmedia lost three channels and Mediaset, Vocento and Unidad Editorial lost two each. The total number of private nationwide channels went from 28 to 19.

This process of legal closures overlapped in time with the liberation of the digital dividend before 1 January 2015. Successive central governments have awarded so much radio spectrum to their respective political clients that by late-2014 they were occupying a large part of the spectrum that, from 2015 on, should have been used by telecommunications companies for $4 \mathrm{G}$ mobile services. This led to a process of replacing antennas and retuning TV sets that was managed in such a short space of time and with such deficiency that by late-2014 it was clear that it would not be completed in time or form. In fact, the Spanish Government delayed the final DTT re- 
tuning, which finally took place on March 31, 2015. Broadcasters, carriers, retailers and viewers needed to adapt networks and antennas to receive the new frquencies, and the risk of people left without DTT was high in some parts of the country.

\section{Conclusions}

We initiated this work with the general hypothesis that in Spain a policy of 'occupation' of the spectrum guided by political and clientelistic interests has always prevailed, which has impeded any professional attempt to define a rational and efficient broadcasting model, both under the Dictatorship and in times of Democracy.

The indices and evidence collected during the fieldwork show that the logic applied during four key, historic moments in the development of the audiovisual model in Spain has marked the form of management, which has remained historically dominated by political criteria and scarcely governed by principles of efficiency, neither economic nor technical. In fact, the policy of occupation of the radio spectrum has been a previous step required in order for governments to develop their clientelistic policies in different processes of awarding radio and television frequencies.

Although the transition to democracy involved greater transparency and control, the form to carry out territorial and political decentralization was a clear example of the primacy of political interests over technical or legal ones; that is, more political than rational. In fact, clientelism and the political instrumentalisation of radio spectrum played a major role in all the tenders, as each government (whether national or regional) tended to grant licences to the companies that it considered to be supportive. Digitalisation and its binary code were a first serious intent of rationality, 
but it is now, when in all of Europe traditional broadcasters feel expelled from their historically occupied frequencies range, that total efficiency could arrive.

In fact, we could say that the process tends to follow the same pattern:

a) The spectrum is occupied,

b) Frequencies are filled more for political than professional motives,

c) Sometimes (digital radio for instance), frequencies are awarded but not used or under-utilized,

d) On other occasions (digital radio again), broadcasters are allowed to reduce the obligations included in the licence to cover the whole territory.

Both the under-utilization and coverage obligations are some of the likely situations experts gave warning about (GRETEL, 2007; RSPG, 2014).

Definitively, the survival of the method for controlling and occupying the spectrum and the persistence of clientelism in the media means we can say that Spain followed the atavistic orientation defined by Jakubowicz and Süskösd (2008). It is also a demonstration of the adaptation capacity of clientelism, one of the fundamental pillars that define the Mediterranean model, according to Hallin and Mancini (2004). To this, the authors add another defining element: the absence of a prevailing 'rational-legal authority'; in its place, a regulation has precedence on the basis of consummated facts or when the international context obliges Spain to comply with standards. In fact, it is sometimes the State bodies themselves (regional and local, but also central administration) that occupy the spectrum and fail to respect the applicable legal framework, catering for the interests of the local political elites. 
From January 1, 2015, it is also necessary to analyse where the liberalization of the spectrum is heading as the different Spanish governments have debated and are debating between compliance with European standards (which are considerably liberalising in themselves) and the inherent historical conception of managing the spectrum more as a political platform than a technological one.

The demands and disputes concerning the spectrum and its way of management are traumatic, but they could be, in the same way, the manner of guaranteeing this rational and efficient use that should not be at odds with the public good.

\section{References}

AIMC (2002) Censo de televisiones locales [Local television census]. October 2002. Madrid: AIMC.

AIMC (2015) 'Resumen general de resultados EGM' [Overall summary of EGM results] . Available at:

http://www.aimc.es/spip.php?action=acceder_document $\& \arg =2877 \& \mathrm{cle}=4 \mathrm{aa} 7 \mathrm{ca} 0 \mathrm{bfe}$ e3e9a848f0e1ebc984975a5ab14fe5\&file=pdf\%2Fresumegm215.pdf Analysys Consulting, DotEcon, Hogan \& Hartson (2004) 'Study on conditions and options in introducing secondary trading of radio spectrum in the european community'. Available at:

http://ec.europa.eu/information_society/policy/radio_spectrum/ $\underline{\text { docs/ref_docs/secontrad_study/secontrad_annexes.pdf }}$ Arboledas, Luis (2009) 'Clientelismo y concentración en la radio española. Comparación entre cuatro comunidades autónomas' [Clientelism and concentration in Spanish radio. A comparison among four autonomous communities]. Revista 
Latina de Comunicación Social, 64: 909-925. Available at: http://www.revistalatinacs.org/09/art/870_UGR/71_107_Luis_Arboledas.html Ala-Fossi, Marko and Bonet, Montse (2015) 'Clearing the Skies? The Sudden Rise of New European Spectrum Policy and Future Challenges for DTT in Finland and Spain'. Paper for session VIII: Conflicts and Contradictions. FACE Conference European Media Policy 2015: New Contexts, New Approaches. Helsinki, Finland April 9-10.

Arboledas, Luis and Bonet, Montse (2014) 'Radio in Spain. European appearance, Franco's legacy'. Javnost -The Public 21(4): 67-82.

Arboledas, Luis and Bonet, Montse (2013) 'Radio on the Iberian Peninsula: autarky, revolution and convergence'. International Communication Gazette 75(2): 205-224. Bonet, Montse (2007) 'Nuevos caminos para la radio. Un proceso productivo digital para un negocio analógico' [New ways for radio. A digital production process for an analogue business]. Telos 73: 27-35

Bonet, Montse and Arboledas, Luis (2011) 'The European exception: Historical evolution of Spanish radio as a cultural industry'. Media International Australia incorporating Culture and Policy Journal 141: 38-48.

Bonet, Montse, Arboledas, Luis and Guimerà, Josep Àngel (2014) 'Past Boundaries, Future Limitations: Spanish Public Service Broadcasting at Risk'. Paper presented at: RIPE@2014 Conference. Tokyo 27-29 of August. Available at: http://ripeat.org/wpcontent/uploads/tdomf/3387/Bonet\%20et\%20al\%20RIPE\%20paper\%202014.pdf. Bonet, Montse; Civil i Serra, Marta and Llinés, Montse (2008) 'Una década de políticas de gestión del espectro radioeléctrico en la Unión Europea (1997-2007). Análisis de las consultas públicas, el marco normativo y las prioridades estratégicas'. [A decade of spectrum management policies in the European Union (1997-2007). 
Analysis of the public consultations, regulatory framework and strategic priorities] Observatorio (OBS*) Journal 7: 41-61. Available at:

http://www.obs.obercom.pt/index.php/obs/article/view/170/222

Bonet, Montse, Corominas, Maria, Fernández Alonso, Isabel and Díez, Mercè (2009)

'Keys to the failure of DAB in Spain'. Journal of Radio and Audio Media 16(1): 83101.

Cullel, Cristina (2011) 'Harmonisation of the digital dividend in the European Union and its impact on national DTT planning in the United Kingdom and Spain'.

Quaderns del CAC 36 XIV(1): 69-77. Available at:

http://www.cac.cat/pfw_files/cma/recerca/quaderns_cac/Q36_Cullell_EN.pdf

Delgado, Juan (2015) 'Reallocating the $700 \mathrm{MHz}$ band: should we do it?'. Emerald

Insight 17(1): 9-21. Available at: http://dx.doi.org/10.1108/info-07-2014-0032

Dunbar-Hester, Christina (2009) 'Free the spectrum!' Activist encounters with old and new media technology'. New Media \& Society 11(1-2): 221-240.

EBU (2012) 'WRC-12 should not put the EU Radio Spectrum Policy Programme at risk' say Europe's Public Broadcasters', Geneva, 13 February 2012. Available at: http://www.ebu.ch/en/union/news/2012/tcm_6-74480.php .

European Commission (2005) 'A market-based approach to spectrum management in the European Union'. Brussels. COM(2005) 400 final. Available at: http://eurlex.europa.eu/legal-content/EN/ALL/?uri=CELEX:52005DC0400 European Commission (2007) 'Reaping the full benefits of the digital dividend in Europe: a common aproach to the use of the spectrum released by the digital swithover'. Brussels. COM(2007) 700 final. Available at: http://eurlex.europa.eu/legal-content/EN/ALL/?uri=CELEX:52007DC0700 
European Commission (2015a) 'On the harmonisation of the 1452-1 $492 \mathrm{MHz}$ frequency band for terrestrial systems capable of providing electronic communications services in the Union'. Brussels. Available at: http://eurlex.europa.eu/legal-content/EN/TXT/PDF/?uri=CELEX:32015D0750\&from=EN European Commission (2015b) '4th Progress Report of the RSPG Working Group on Efficient Awards and Spectrum Use'. Brussels. DG CNECT/B4/RSPG Secretariat. Available at: https://circabc.europa.eu/d/a/workspace/SpacesStore/cf0687bc-63a1498e-b298-dea76e4db08c/RSPG15-605-4th_Progress_Report_Awards.pdf Fernández, Isabel and Fernanda Santana (2000) Estado y medios de comunicación en la España democrática [State and mass media in democratic Spain]. Madrid: Alianza Editorial.

Fernández-Quijada, David and Arboledas, Luis (2013) 'The Clientelistic Nature of Television Policies in Democratic Spain'. Mass Communication and Society 16(2): $200-221$.

García Leiva, Mª Trinidad (2009) 'El dividendo digital: desafíos, oportunidades y posiciones nacionales' [The digital dividend: challenges, opportunities and national positions]. Revista Latina de Comunicación Social 64: 424-436. Available at: http://www.revistalatinacs.org/09/art/35_834_37_ULEPICC_19/Trinidad_Garcia_Lei va.html_

García-Leiva, Ma Trinidad (2013) 'El futuro del espectro radioeléctrico: entre las políticas de comunicación y el mercado' [The future of radio spectrum: between communication policies and market], pp. 111-138 in G. Mastrini, A. Bizberge and D. De Charras (eds) Las políticas de comunicación en el siglo XXI [The communication policies in the XXI century]. Buenos Aires: La Crujía Ediciones. 
García Leiva, $\mathrm{M}^{\mathrm{a}}$ Trinidad and Starks, Michael (2009) 'Digital switchover across the globe: the emergence of complex regional patterns'. Media, Culture and Society 31(5): 787-806.

GRETEL [Grupo de Regulación de las Telecomunicaciones] (2004) 'Novedades en la gestión del espectro radioeléctrico. Comercio Secundario (II). La posición de GRETEL ante la consulta pública de la CE' [Developments in the management of radio spectrum. Secondary trading (II). GRETEL position before the public consultation of the EC]. Bit 146. Available at: http://www.gtic.ssr.upm.es/ccoit/Docs/articulos BIT/Articulo Bit_GRETEL 2004_Comercio secundario II.pdf.

GRETEL [Grupo de Regulación de las Telecomunicaciones] (2007) 'La evolución de la gestión del espectro radioeléctrico’ [Evolution of radio spectrum management]. Available at: http://www.coit.es/index.php?op=estudios_218.

Guimerà, Josep Àngel (2006) La televisió local a Catalunya; gestació, naixement i transformacions (1976-2005) [Local television in Catalonia: preparation, start and transformations]. PhD dissertation. Cerdanyola del Vallès: Universitat Autònoma de Barcelona.

Guimerà, Josep Àngel and Bonet, Montse (2012) ‘El modelo de negocio en cadena: del éxito radiofónico al fracaso televisivo' [The network-business model: from radio success to television failure]. Quaderns del CAC 38 XV(1): 100-107.

Guimerà, Josep Àngel (2014) Les polítiques de mitjans de comunicació durant els governs de Jordi Pujol. Premsa, ràdio i televisió en el procés de reconstrucció nacional de Catalunya (1980-2003) [Media policies during Jordi Pujol's governments. Newspapers, radio and television in the process of national reconstruction of Catalonia]. Barcelona: Proa. 
Guimerà, Josep Àngel and Blasco, José Joaquín (2012) 'La formación histórica del sistema televisivo autonómico público en España (1982-2011)’ [Historical development of the public regional television system in Spain], pp. 33-57 in Miguel, J. C. and Casado, M. Á. (coords) Televisiones autonómicas: evolución y crisis del modelo de proximidad [Regional televisions: evolution and crisis of proximity model]. Madrid: Gedisa.

Hale, Julian (1975) Radio Power: Propaganda and International Broadcasting. Philadelphia: Temple University Press.

Hallin, Daniel, Papathanassopoulos, Stylianos (2002) 'Political clientelism and the media: southern Europe and Latin America in comparative perspective'. Media, Culture and Society 24(2): 175-196.

Hallin, Daniel and Mancini, Paolo (2004) Comparing media systems: three models of media and politics. Cambridge: Cambridge University Press.

Hellman, Heikki (2010) 'Liberal turn in media policy: the case of Finland's digital television'. International Journal of Digital Television 1(2): 193-213.

Hendricks, John Allen; Bonet, Montse; Hallett, Lawrie, Kulikova, Svetlana, Chen, Chwen Chwen (2011) 'International Radio Regulation: An Overview', pp. 17-37 in Hendricks, J. A. (ed) The Palgrave Handbook of Global Radio. New York: Palgrave MacMillan.

Iosifidis, Petros (2011) 'Growing pains? The transition to digital television in Europe'. European Journal of Communication 26(1): 3-17.

ITU (2006) 'Recommentation SM.1046 : Definition of spectrum use and efficiency of a radio system'. Available at: https://www.itu.int/rec/R-REC-SM.1046/en 
Jakubowicz, Karol (2004) 'Ideas in our heads. Introduction of PSB as Part of Media System Change in Central and Eastern Europe'. European Journal of Communication 19(1):53-74.

Jakubowicz, Karol (2008) 'Finding the Right Place on the Map: Prospects for public service broadcasting in post-communist countries', pp. 101- 124 in K. Jakubowicz and M. Sükösd (eds) Finding the Right Place on the Map: Central and Eastern European Media Change in a Global Perspective Bristol: Intellect Books, Chicago: The University of Chicago Press.

Jakubowicz, Karol and Sükösd, Miklós (2008) 'Twelve Concepts Regarding Media System Evolution and Democratization in Post-Communist Societies', pp 9-40 in K. Jakubowicz and M. Sükösd (eds) Finding the Right Place on the Map: Central and Eastern European Media Change in a Global Perspective Bristol: Intellect Books, Chicago: The University of Chicago Press.

Ko, Hsien-Tang; Lee, Chien-Hsun; Lin, Jia-Huei; Chung, Kay and Chu, Nan-Shiun (2014) 'Television white spaces: learning from cases of recent trials'. International Journal of Digital Television 5(2): 149-167.

Lewis, Peter M. and Booth, Jerry (1990) The Invisible Medium: Public, Commercial, and Community Radio. Washington. D.C.: Howard University Press. Massaro, Maria (2013) 'What is the digital dividend? State of play in Europe'. Luiss Guido Carli University Master's Degree in Economics, Rules and Markets, Rome, Italy 2013. Available at: http://tesi.eprints.luiss.it/11435/1/massaro-maria-tesi2013.pdf

Miège, Bernard (ed) (1990) Médias et Communication en Europe. Grenoble: PUG. Mullooly, Morgan (2012) The 700MHz spectrum band: market drivers and harmonisation challenges worldwide. Research report. London: Analysys Mason. 
RSPG (2014) 'Towards best practice in spectrum use in the EU'. Presentation by Peter Stuckmann (Head of Sector - Spectrum Policy) at RSGP/BEREC event. Brussels. Available at:

http://berec.europa.eu/files/workshop2014/EC\%20DG\%20CONNECT\%20presentatio n.pdf

Papatheodorou, Fotini and Machin, David (2003) 'The umbilical cord that was never cut. The post-dictatorial intimacy between the political elite and the mass-media in Greece and Spain'. European Journal of Communication 18(1): 31-54.

Schumann, Robert (2011) 'Digital Dividend harmonisation in Europe'. Presentation to ATU Digital Migration and Spectrum Policy Summit, Nairobi, 30 November 2011. London: Analysys Mason. Available at: http://www.gsma.com/spectrum/wpcontent/uploads/DigitalDividend/DDtoolkit/uploads/assets/downloads/04/digitaldividend-harmonisation-in-europe.pdf 